\title{
Antalya Manavgat İlçe Milli Eğitim Müdürlüğü’ne Bağlı İlköğretim Okullarında Fiziksel Çevre Sağlık Koşullarının Değerlendirilmesi
}

\author{
Mukaddes ÖRS \\ Amasya Üniversitesi Să̆lıkYüksek Okulu, Amasya,Türkiye,mukaddesors@hotmail.com
}

\begin{abstract}
Özet
$\mathrm{Bu}$ araştırma, Manavgat İlçesinde çevre sağlı̆̆ı bakımından kamu ilköğretim okullarının durumunu saptamayı amaçlamaktadır. Tarama modelinde olan bu araştırmanın evreni Manavgat ilçesinde bulunan kamu ilköğretim okullarından görev yapan okul yöneticilerinden oluşmaktadır. Veriler 10 ilköğretim okulu yöneticisinden toplanmıştır. Her okulda görev yapan bir yönetici (Müdür, müdür vekili veya müdür yardımcısı) örnekleme alınmıştır. Kamu ilköğretim okullarında görev yapan okul yöneticilerinin okullarında fiziksel çevre sağlığını değerlendirmeye ilişkin maddelere vermiş oldukları yanıtların, sayı ve yüzdeleri hesaplanmıştır. Araştırma bulgularına göre, fiziksel çevre sağlığı açısından okulların hemen tamamının okul çevre sağlığı kriterlerine uygun olmadığı saptanmıştır.
\end{abstract}

Anahtar Kelimeler: İlköğretim okulları, sağlıklı okul çevresi, öğrenci başarısı

An Evaluation of The Physical Environmental Health Conditions of Elementary Schools in Manavgat District National Education Directorate of Antalya

\begin{abstract}
This research aims at determining status of public elementary schools on terms of environmental health in Manavgat district. The universe of this research which is in survey model consists of school managers who working in public elementary schools which are located in Manavgat district. Data collected from 10 elementary school administrator. Numbers and percentage of responses given by school administrators who work in public school, elementary school for assessing the health of physical environment were calculated. According to the findings, it has been identified that almost all schools in terms of physical environment health does not meet the criteria of school environment health.
\end{abstract}

Keywords: Elementary schools, healthy school environment, student achievement

\section{Giriş}

Okullar, ülkemiz nüfusunun önemli bir oranını oluşturan yaklaşık 20 milyon okul çağı (okul öncesi, ilköğretim ve orta öğretim) çocuğunun bulunduğu kurumlardır (Milli Eğitim Bakanlığı [MEB], 2010-2011). Bir toplumda, sosyal ve ekonomik çevrenin eğitsel gereksinimlerini karşılayan okul, eğitim sisteminin en önemli öğelerinden biridir. Eğitim sistemi içinde okulların temel işlevi, öğrencilere istenilen davranışları kazandırmak ve bu davranışların kazandırılması için çevreyi gerekli biçimde düzenlemektir (Taymaz, 2003). 
Amerika Çocuk Sağlığı ve Hastalıkları Akademisi (The American Academic of Pediatrics, 1993), "sağlıklı bir okul çevresini”, öğrenci ve çalışanları ani yaralanma ya da hastalıklardan koruyan ve gelecekte hastalık veya özür meydana getirebilecek risk faktörlerine karşı tedbir niteliğinde aktivite ve yaklaşımlar sunan bir okul çevresi olarak tanımlamıştır (WHO, 2008). Okul çevresi gerek çalışanlar gerekse öğrencilerin sağlığını, güvenliğini, davranış ve alışkanlıklarını, çalışma ve öğrenme verimliliğini etkileyen bir ortamdır. İnsan sağlığını olumsuz etkileyen çevresel faktörler, okul sağlığını da olumsuz etkilemektedir (Temel ve diğerleri, 2006).

Sağlıklı bir fiziksel çevre, yaralanma ve hastalıkların önünü kesmeye yardım eden ve sağlığı iyileştirici eylemlere yardım eden temiz ve güvenli bir ortamdır. Okula gidiş gelişi kapsayan her yer bu çevreye dahildir ve güvenliği sağlamak, yaralanmaları önlemek, zehirli maddelerden etkilenmeyi en aza indirmek ve aşırı kalabalığın önüne geçmek, temizlik, 1şıklandırma, temiz içme suyu, lavabo kullanımı, geniş oyun sahası ve oyun sahasının iyi korunuyor olması (ağaçlık, kalabalık bölgeler), geri dönüşüm atıklarının kullanımı, gürültü, temiz hava ve diğer çevresel standartlara kadar birçok konuyu içine almaktadır (Spurrell, 2006).

Bir okulun fiziksel çevresi öğrencilerin ve okul personelinin sağlı̆̆ını etkilemektedir. Sağlıklı bir okul çevresi, tehlikeler azaltılarak, destekleyici politikalar uygulanarak ve öğrencilerin ellerinden gelenin en iyisini sergileyebilecekleri bir atmosfer yaratılarak öğrencilerin sağlığına katkı sağlar (Henderson ve Rowe, 1998). Raporlar, fiziksel çevre öğrenciler için elverişli olduğunda, sağlik koşullarının da gelişeceğini ve beraberinde de daha az yaralanma ve hastalık riski getireceğini savunmaktadır. Yetersiz çevre koşullarının sağlıksızlığa neden olduğunu gösteren birçok kapsamlı belgeler bulunmaktadır (Leger, 1999).

Okullarda fiziksel çevreden kaynaklanan sorunlar çocukların öğrenme kapasitelerini ve okul sağlığını önemli derecede etkiler (Okul Sağlığı Kongresi, 1999). Okula güvenli, pozitif fiziksel bir çevre ile devam eden öğrencilerin, kasitsız yaralama, şiddet, tütün, alkol ve uyuşturucu kullanımını veya okul başarısızlığını tecrübe etme olasılıkları daha azdır (Jones ve diğerleri, 2007). Literatürde mevcut olan rapor ve çalışmalar öğrencilerin sağlıklı olduklarında daha iyi öğrendiklerini gösteren çeşitli deliller sunmaktadır (Leger, 1999). Dolayısıyla okulun nereye yapılacağı, nasıl dizayn edileceği, nasıl yürütüleceği, fiziksel okul çevresiyle ilgili yönetmelik ve programların uygulaması hakkındaki kararlar çocukların potansiyel öğrenme ve sağlıklarıyla ilgilidir (Jones ve diğerleri, 2007).

Sağl1klı öğrenciler yetiştirmek için sağlıklı okul çevresi, bir başka deyişle okulun fiziksel çevresinin uygunluğu şarttır. Okul çevresi gerek çalışanların, gerekse öğrencilerin sağlığını, güvenliğini davranış ve alışkanlıklarını, çalışma ve öğrenme verimliliğini etkileyen bir ortamdır. Öğrenciler ve personel yaşamlarının önemli bir kısmını okulda geçirdiklerinden fiziksel çevre güvenli olmalı, sağlığı tehdit eden etkenlerden arınmış ve olumlu sağlık davranışını geliştiren şartları taşımalıdır (Sur ve Uz, 1994). Amerikan Okul Sağlığı Derneği sağlıklı okul çevresi için; sigarasız, uyuşturucusuz ve şiddetten uzak bir çevre oluşturulmasını; okul binasının engelli bireylerin kullanabileceği şekilde düzenlenmesini; 1sıtma, havalandırma, aydınlatma ve ses izolasyonun standartlara uygun olmasını; su, hava ve diğer çevresel etmenlerin kontrolünü önermektedir (Aktaran: $\mathrm{Ku}$ Band, 1995).

Türkiye'de yapılan birkaç araştırma sonucunda okulların fiziksel çevre koşullarının yetersiz olduğu belirlenmiştir. Bu araştırmaların sonuçlarına göre, (Topçu,1978; Polat, 1998; Karabayır, 2004; Aydoğdu, 2007; Babayiğit ve diğerleri, 2010) Türkiye'de ilköğretim okullarının büyük çoğunluğunun hem geçmişte hem de günümüzde fiziksel çevre sağlı̆̆ açısından yetersiz olduğu, bu yetersizliğin aradan geçen zamana karşın varlığını sürdürdüğü söylenebilir. Okullarda fiziksel çevreden kaynaklanan sorunların çocukların öğrenme kapasitelerini ve okul sağlığını önemli derecede etkilediği uzun y1llar önce dile getirilmiş olan bir saptamadır (Juszcak,1999).

Çocuklar, kritik gelişim dönemleri sürecinde gün içindeki zamanlarının çoğunu okul ortamında geçirmektedirler. Dolayısıyla sağlıklı öğrenciler için okul çevresinin öğrencilere örnek oluşturacak şekilde yapılanması gerekir. İnsan sağlı̆ıını olumsuz etkileyen çevresel etmenlerin hepsinin, okul 
çevre sağlığını da tehdit eden unsurlar olduğu bilinmektedir. Okul çevresi okulun yapımı aşamasında özen gösterilmesi gereken konular arasındadır. Okullarda çocuklar, sağlıksız içme suları, yetersiz ve dengesiz beslenme, yetersiz sanitasyon, kirli hava, yetersiz çöp toplama sistemleri, gürültü ve kazalar gibi bir çok çevresel risk ve tehlikeyle karşı karşıya kalmaktadırlar. Çocukların bu çevresel risk ve tehlikelerden korunabilmesi için okulların fiziksel çevre koşullarının değerlendirilmesinde kullanılan ölçütlerin ayrıntılı bir şekilde tanımlanması gerekmektedir. Okul çevresi hazırlanan yasa, yönetmelik ve standartlarla düzenlenmektedir. Bu araştırma, Antalya İli Manavgat İlçesinde fiziksel çevre sağlığı bakımından kamu ilköğretim okullarının durumunu saptamayı amaçlamaktadır.

\section{Yöntem}

\section{Araştırma Modeli}

Antalya İli Manavgat İlçesindeki Milli Eğitim Bakanlığına bağlı kamu ilköğretim okul yöneticileri (müdür, müdür vekili, müdür yardımcıları)'nin görüşlerine göre okulların fiziksel çevre sağlı̆̆ bakımından mevcut durumunu ortaya koymaya çalışan araştırma, durum saptamaya yönelik betimsel bir çalışma olup tarama modeli esas alınarak yürütülmüştür.

\section{Araştırmanın Evreni}

Bu araştırmanın evreni, Antalya İli Manavgat İlçesi Belediye sınırları içinde bulunan Milli Eğitim Bakanlığı'na bağlı kamu ilköğretim okullarında görev yapan yöneticilerden oluşmaktadır. Araştırmanın evreninde on (10)kamu ilköğretim okulu bulunmaktadır. Bu kamu ilköğretim okullarında 44 okul yöneticisi (müdür, müdür yardımcısı, müdür vekili) görev yapmakta (Antalya Milli Eğitim Müdürlüğü, 2010).

\section{Araştırmanın Örneklemi}

$\mathrm{Bu}$ araştırmanın örneklemine, araştırma evreni tanımlandıktan sonra, okulların bulundukları mahalleler dikkate alınarak okulların tamamı örnekleme alınmıştır. Her okulda görev yapan yönetici sayıları belirlenmiştir. Her okulda görev yapan bir yönetici (müdür, müdür vekili veya müdür yardımcısı) örnekleme alınmıştır.

\section{Veri Toplama Aracının Geliştirilmesi}

$\mathrm{Bu}$ araştırmada Antalya İli Manavgat ilçesi Belediye sınırları içinde bulunan Milli Eğitim Bakanlığına bağlı kamu ilköğretim okulunda görev yapan yöneticilerin ilköğretim okullarının fiziksel çevre sağlığına ilişkin görüşlerinin neler olduğunun belirlenmesi amacıyla araştırmacı tarafindan bir anket geliştirilmişsir.

Fiziksel Çevre Sağlı̆̆ı araştırması yönetici bilgi ölçeğini hazırlamak için konuyla ilgili gerek yurtiçinde gerek yurt dişında alanyazın incelenmiştir. Alanyazın incelemesi sonucunda fiziksel çevre sağlığı yönetici bilgisi ölçeği ile ilgili ifadeleri içeren 100 maddelik bir madde havuzu oluşturulmuştur. Ön değerlendirmeler sonunda bu havuz 60 maddelik veri toplama taslağı haline dönüştürülmüştür.

Anket taslağında, okul yöneticilerinin fiziksel çevre sağlık bilgisi ölçeği, Dünya Sağlık Örgüt (WHO)'nün "Fiziksel Okul Çevresi, Sağlık Teşvik Okulu'nun Gerekli Bir Bileşeni”, “Okul Binası Yeterliği İçin 31 Kriterin Önceliklendirilmesi" (Earthman,2004). U.K. Derby City Bog Standartları (2009), Okul Sağlık Politikaları ve Program Çalışmasından (CDC, 2006) yararlanılarak hazırlanmıştır. Hazırlanan ölçek taslağı, yüz geçerliği-kapsam geçerliği için uzman kişilerin görüşlerine sunulmuştur Anket taslağı, yaşam boyu öğrenme ve yetişkin eğitimi, eğitim yönetimi ve politikası, istatistik alanlarında uzman olan kişilerin görüşleri doğrultusunda yeniden düzenlenmiş, ayrıca bir grup yöneticinin de görüşleri alınmıştır. Alınan uzman görüşleri doğrultusunda, 60 maddeden 45 maddeye indirilmiş, bazı maddeler anlaşırlık, açıklık, Türkçe kurallarına uygunluk gibi ilkeler dikkate alınarak yeniden yazılmıştır. Böylece taslak ölçek 5 maddelik kişisel bilgiler ( görev, yaş, cinsiyet, kıdem, eğitim) ile toplam 50 maddeye dönüştürülmüş ve ön uygulamaya hazır hale getirilmiştir. 
Okul yöneticilerinin Okullarında Fiziksel Çevre Sağlı̆̆ını değerlendirme bilgilerini ölçme aracının geçerlik çalışmalarının sürdürülmesi ve güvenirliğinin belirlenmesi için ön uygulaması yapılmıştır. Ön uygulamada kamu ilköğretim okullarında görev yapan yöneticilere 10 ölçek dağıtılmış ve sonuçlar değerlendirmeye alınmıştır. Veri toplama formları esas uygulamaya geçmeden önce araştırma yapılacak okulları etkilemeyecek okullara uygulanmıştır. Bu anket taslağında ön deneme sonucu saptanan eksikler ve anlaşılmayan kısımlar düzeltildikten sonra telefonla alınan randevu tarihlerinde okul yöneticileri ile görüşme yapmak için ilgili okullara, 14 Haziran ve 19 Haziran 2010 tarihleri arasında gidilerek veri toplanmıştır.

$\mathrm{Bu}$ formda 50 soru bulunmaktadır. Bu form aracılığı ile ilköğretim okullarının çevresi, binası, bahçesi, sınıfları ve koridorların hijyeni, okul tuvaletleri, beslenme ve okul kantini değerlendirilmiştir. Formdaki soruları evet, hayır, bilmiyorum, var, yok olarak ifade etmeleri istenmiştir. Bu bölümde açık uçlu sorulara da yer verilmiştir.

\section{Verilerin Analizi}

Kamu ilköğretim okullarında görev yapan okul yöneticilerinin okullarında fiziksel çevre sağlığını değerlendirmeye ilişkin maddelere vermiş oldukları yanıtların, sayı ve yüzdeleri hesaplanmıştır. Verilerin "İlköğretim Okullarında Okul Çevre Sağlığı Değerlendirme Kriterleri” evet, hayır, uygun, uygun değil şeklinde gruplandırılmıştır. Bu kriterlere göre standartları karşılayan veriler "uygun", standartları karşılamayan veriler "uygun değil" şeklinde değerlendirilmiştir.

\section{Bulgular}

\section{İlköğretim Okulu Yöneticilerinin Demografik Özellikleri}

Görüşülen 10 yöneticiden 7'si (\% 70) müdür, 3'ü (\% 30)' müdür yardımcısı unvanını taşımaktadır. Araştırmaya katılan okul yöneticilerin \% 50'si 41-50 yaşları arasındadır. Bunu 31-40 yaşlarındaki (\% 40) ve 51 yaş ve üzerindeki yöneticiler (\% 10) izlemektedir.

İlköğretim okul yöneticilerinin büyük bir bölümünü (\% 90) erkek yöneticiler oluştururken kadın yöneticilerin sayısının oldukça düşük (\%10) olduğu dikkat çekmektedir. Mesleki kıdem açısından katılımcıların \%50'sini 21 yıl ve üstünde kıdemi olan yöneticiler, \% 40'ını ise 6-15 yıl arasında kıdemi olan yöneticiler oluşturmaktadır. Eğitim durumu açısından incelendiğinde katılımcıların \% 90'ını lisans mezunu, \%10’nu ise önlisans mezunlarının oluşturduğu görülmektedir.

\section{Yöneticilerin Fiziksel Çevre Sağlığına İlişkin Bilgileri}

İlçe merkezinde bulunan on İlköğretim okulunun yedisinin ikili öğretim yapan ilköğretim okulları ve üçünü tekli öğretim yapan ilköğretim okulları oluşturmaktadır. Araştırma kapsamına alınan okulların 2/3'ünden fazlasının öğretim şekli ikili öğretimdir.

Okulların altısının 3 katlı ve dördünün 4 ve daha fazla katlı olduğu görülmektedir. Okulların \% 90'nında 2. ve daha yukarı katlarında pencerelerde korkuluk olmadığı belirlenmiştir. Okul Çevre Sağlığı Standartlarına göre okul birden fazla katlı yapılmış ise üst katlardaki pencerelerden öğrencilerin sarkmasını önleyecek korkuluk (demir parmaklık) gibi tedbirler alınmalıdır (Pekcan, 2005, 21).

Okulların 7/10'nin öğrenci sayısı 1000-2000 arasında iken, öğrenci sayısı 2000'nin üzerinde olan bir okul, 1000'nin altında olan iki okul bulunmaktadır. Manavgat ilçesinde derslik başına düşen ortalama öğrenci sayısının 41 olduğu görülmektedir. Bir okulda derslik başına düşen öğrenci sayısının 11, sekiz okulda derslik başına düşen öğrenci sayısının 30’un üzerinde olduğu görülmektedir. 
Tablo 1. Yöneticilerin, “Okulların Fiziksel Çevresiyle İlgili Bazı Özelliklerine İlişkin” Sorulara Verdikleri Yanıtların Dă̆ılımı

\begin{tabular}{|c|c|c|c|}
\hline \multicolumn{4}{|c|}{ Okulda Revir Var mı Sorusuna Verdikleri Yanıtların Dağılımı } \\
\hline & Kişi sayısı & \multicolumn{2}{|c|}{$(\%)$} \\
\hline Var & 3 & \multicolumn{2}{|c|}{30.0} \\
\hline Yok & 7 & \multicolumn{2}{|c|}{70.0} \\
\hline Toplam & 10 & \multicolumn{2}{|c|}{100.0} \\
\hline \multicolumn{4}{|c|}{ Revirde bir İlk yardım dolabı var mı Sorusuna Verdikleri Yanıtların Dağılımı } \\
\hline & Kişi sayısı & \multicolumn{2}{|c|}{$(\%)$} \\
\hline Var & 8 & \multicolumn{2}{|c|}{80,0} \\
\hline Yok & 1 & \multicolumn{2}{|c|}{10,0} \\
\hline Cevap Vermeyen & 1 & \multicolumn{2}{|c|}{10,0} \\
\hline Toplam & 10 & \multicolumn{2}{|c|}{100,0} \\
\hline \multicolumn{4}{|c|}{ Revirde Görev Yapan Bir Hemşire Var mı” Sorusuna Verdikleri Yanıtların Dağılımı } \\
\hline & & Kişi Sayısı & $(\%)$ \\
\hline \multicolumn{2}{|l|}{ Evet } & 1 & 10,0 \\
\hline \multicolumn{2}{|l|}{ Hayır } & 8 & 80,0 \\
\hline \multicolumn{2}{|l|}{ Toplam } & 9 & 90,0 \\
\hline \multicolumn{2}{|l|}{ Yanit Vermeyen } & 1 & 10,0 \\
\hline \multicolumn{2}{|l|}{ Toplam } & 10 & 100,0 \\
\hline \multicolumn{4}{|c|}{ Okul Binasının Duvarlarının Yalıtımı Var mı" Sorusuna Verdikleri Yanıtların Dağılımı } \\
\hline & & Kişi Sayısı & $(\%)$ \\
\hline \multicolumn{2}{|l|}{ Evet } & 3 & 30.0 \\
\hline Hayır & & 7 & 70.0 \\
\hline Toplam & & 10 & 100.0 \\
\hline
\end{tabular}

Tablo 1'de görüldüğü üzere on ilköğretim okulundan 7'sinde revir olmadığ1 tespit edilmiştir. On ilköğretim okulunun 8'inde okullarda ilkyardım dolabı bulunmaktadır. Araştırma kapsamındaki on ilköğretim okulunun 9'unda hemşire bulunmadığı belirlenmiştir. Araştırma kapsamındaki on okul binasının 7'sinde duvarlarının nem, ses ve ısıya karşı yalıtımın sağlanmadığı görülmektedir. $\mathrm{Bu}$ okulların OÇSS'ye (Okul Çevre Sağlı̆̆ 1 Standartlarına) uygun olmadığı söylenebilir. On ilköğretim okulunun 8'inde suların hiç kesilmediği ve okulların tamamının su kaynağının şebeke suyu olduğu ve sadece bir okulda şebeke suyu, su deposu ve su tankeri bulunduğu belirlenmiş̧tir.

Yöneticilerin tamamı okullarının bahçeye sahip olduklarını belirtmiştir. On okul bahçesinden 7'sinde öğrenci başına $1 \mathrm{~m}^{2}$ ile $3 \mathrm{~m}^{2}$ arasında bir alan düşmektedir. Oysa okul bahçelerinin en az $400 \mathrm{~m}^{2}$ ve öğrenci basına $5 \mathrm{~m}^{2}$ alan düşecek şekilde olması gerekir (Çağlayaner ve Gönenli, 1998; Karasolak, 2009). Buna göre incelenen on okuldan yalnızca üçünde öğrenci başına düşen bahçe alanının yeterli olduğu belirlenmiştir. 
Tablo 2. Yöneticilerin, Okulların Bahçesine İlişkin Bazı Sorulara Verdikleri Yanıtların Dă̆ılımı

\begin{tabular}{|c|c|c|}
\hline Okul Bahçe Zemini & Okul sayıs1 & $(\%)$ \\
\hline Asfalt & 6 & 60,0 \\
\hline Asfalt ve Beton & 3 & 30,0 \\
\hline Asfalt ve Parke & 1 & 10,0 \\
\hline Toplam & 10 & 100,0 \\
\hline \multicolumn{3}{|l|}{$\begin{array}{l}\text { Okul bahçesinin çocukların oyun oynamasına uygunluk } \\
\text { Durumu }\end{array}$} \\
\hline Evet & 10 & 100,0 \\
\hline \multicolumn{3}{|l|}{$\begin{array}{l}\text { Okul bahçesi çocukların hangi tür oyunları oynamasına } \\
\text { uygun? }\end{array}$} \\
\hline Diğer dahil hepsi & 7 & 70,0 \\
\hline $\begin{array}{l}\text { İp, Voleybol, Basketbol ve Futbol } \\
\text { oynanmasına }\end{array}$ & 2 & 20,0 \\
\hline $\begin{array}{l}\text { İp, Voleybol ve Basketbol } \\
\text { oynanmasına }\end{array}$ & 1 & 10,0 \\
\hline Toplam & 10 & 100,0 \\
\hline Var & 10 & 100,0 \\
\hline $\begin{array}{l}\text { Okul çöplerinin biriktirildiği çöplük oyun alanından uzak } \\
\mathrm{m} \text { ? }\end{array}$ & Okul sayısı & $(\%)$ \\
\hline Evet & 8 & 80,0 \\
\hline Hayır & 2 & 20,0 \\
\hline Toplam & 10 & 100,0 \\
\hline \multicolumn{3}{|l|}{ Okul bahçesinin çevre duvarı var mı? } \\
\hline Evet & 10 & 100,0 \\
\hline
\end{tabular}

Tablo 2'de görüldüğü üzere yöneticilerin verdiği bilgiler ve araştırmacının gözlemleri doğrultusunda, araştırmaya alınan okulların tamamında okul bahçe zeminin çocukların oyun oynamasına uygun olmayan materyallerle kaplı olduğu, ancak okulların tamamında okul bahçesinde çocukların çeşitli oyunları oynamasına olanak tanındığı görülmektedir. Bu durum, on ilköğretim okulunun tamamında okul bahçe zeminlerinin çocukların oyun oynamasına uygun olmadığını ortaya koymaktadır.

On ilköğretim okulunun tamamında okul bahçelerinde çöp kutularının mevcut olduğu, ancak okulların 2'sinde okul çöplerinin biriktirildiği çöplüğün, oyun alanından uzak olmadığı belirlenmiştir. Okulların 2'sinin standartlara uygun olmadığı görülmektedir. Okul müdürleri okulların tamamında okul bahçesinin çevre duvarı olduğunu belirtmektedir. Okulların tamamında kız ve erkek öğrenci tuvaletlerinin bulunduğu görülmüştür. Okulların dördünde 100 civarında kız öğrenci için bir tuvalet kabini ve dört okulda da 50'nin altında kız öğrenci için bir tuvalet kabini mevcuttur.

Üç okulda 100'ün üzerinde erkek öğrenci için bir tuvalet kabini mevcutken, dört okulda da 50 ve üzerinde erkek öğrenci için bir tuvalet kabini bulunmaktadır. U.K. National Bog (Derby City Bog) Standartlarına göre 5 yaşın üstündeki her $15 \mathrm{kız}$ ve erkek öğrenci için bir tuvalet kabini uygundur (U.K. National Bog Standartları, 2009), ancak bu standartlara yaklaşan bir okul bulunmaktadır. İlköğretim okullarının tamamına yakınında erkek öğrenci tuvaletlerindeki kabin sayısının yeterli olmadığı görülmektedir.

Okul müdürleri okulların tamamının tuvaletlerinde sürekli olarak sabun bulundurduğunu belirtmektedir. Tablo 3'de görüldüğü gibi okulların \% 60'ında tuvalet kăğdı bulunmadığı belirlenmiştir. 
Tablo 3: Yöneticilerin, “Öğrencilerin Tuvaletlerinde Tuvalet Kă̆ıdı Var mı?” Sorusuna Verdikleri Yanıtların Dağılımı

\begin{tabular}{|l|c|c|}
\hline & Okul sayıs & $(\%)$ \\
Var & 4 & 40,0 \\
\hline Yok & 6 & 60,0 \\
\hline Toplam & 10 & 100,0 \\
\hline
\end{tabular}

Tablo 4: Yöneticilerin, "Öğrenci Velilerinin Gelir Durumuna Göre Okul Tuvaletlerinde Tuvalet Kağıdı Var mı?" Sorusuna Verdikleri Yanıtların Dă̆glımı

\begin{tabular}{|l|c|c|c|c|}
\hline & \multicolumn{3}{|c|}{ Öğrencilerin Ailelerinin Gelir Durumları } \\
\hline \multicolumn{2}{|l|}{ Tuvalet Kağıdı Bulundurma Durumu } & & Orta & Kötü \\
\hline Var & Okul Sayısı & 0 & 4 & 0 \\
\hline Yok & Okul Sayısı & 1 & 2 & 3 \\
\hline
\end{tabular}

Öğrenci velisinin gelir durumu iyi olan okulda tuvalet kağıdı bulunmadığı ve öğrenci velilerinin gelir durumu orta olan okullarda tuvalet kağıdı bulunduğu belirlenmiştir. Okulların beşinde, yüz ve yüzün üzerinde kız öğrenci için bir lavabo varken, üç okulda 50 ve civarında öğrenci için bir lavabo bulunmaktadır. Beş okulda yüzün üzerinde erkek öğrenci için bir lavabo varken, 3 okulda ellinin üzerinde erkek öğrenci için bir lavabo bulunduğu gözlendi. U.K. National Bog (Derby City Bog) Standartlarına göre 5 yaşın üstündeki her on beş kız ve erkek öğrenci için bir lavabo bulunması uygundur, ancak araştırma kapsamına alınan ilköğretim okulların \% 90'nının lavabo sayısı bakımından U.K. National Bog (Derby City Bog) Standartları kriterlerine uygun olmadığı görülmektedir.

Tablo 5: Yöneticilerin, “Okul Tuvaletlerine Ne Kadar Sıklıkla Temizlik Yapılmaktadır?” Sorusuna Verdikleri Yanıtların Dă̆ılımı

\begin{tabular}{|l|c|c|} 
& Okul Sayıs1 & $\mathbf{( \% )}$ \\
\hline Günde $2 \mathrm{kez}$ & 2 & 20,0 \\
\hline Günde $3 \mathrm{kez}$ & 3 & 30,0 \\
\hline Her tenefüs & 5 & 50,0 \\
Toplam & 10 & 100,0 \\
\hline
\end{tabular}

Tablo 5'de görüldüğ̈̈ gibi, okulların yarısının her teneffüs sonrası tuvaletlerinin temizlendiğ söylenebilir. Okulların \% 20'sinde tuvaletlerin günde iki kez ve \% 30'unda da günde üç kez temizlendiği görülmektedir.

Yöneticiler, okulların tamamında lavabo ve diğer kullanılan eşyaların öğrencilerin boylarına uygun olduğunu söylemektedir. Ancak, araştırmacının gözlemlerine göre bir okul hariç diğer okulların lavabo ve diğer eşyaları çocukların boylarına uygun değildir. Çünkü sadece bir okulda anasınıfı öğrencilerinin yaşlarına uygun tuvalet ve lavabo bulunmaktadır. $\mathrm{Bu}$ durum okul müdürlerinin bu konuda bilgi eksikliğini ve öğrenme ihtiyaçları olduğunu göstermektedir. U.K. National Bog (Derby City Bog) Standartlarına göre ilköğretim okullarındaki lavaboların ve diğer kullanılan eşyaların yükseklik ve genişliğinin öğrencilerin yaşlarına uygun olması gerekmektedir. İlköğretim okullarında lavabo yüksekliklerinin U.K. National Bog (Derby City Bog) Standartları Kriterlerine uygun olmadığı görülmektedir. 
Tablo 6. Okulların Sinıflarıyla İlgili Bazı Fiziksel Özelliklerin Durumu

\begin{tabular}{|l|c|c|}
\hline & Okul sayıs1 & $(\%)$ \\
\hline Sinıflarda Çöp Kutusu Bulundurma Durumu & 10 & 100,0 \\
\hline Sinıflarda Çöp Kutuları Nasıldır & 10 & 100,0 \\
\hline Kapaklı ve İçine Poşet Geçirilmiş & 10 & 100,0 \\
\hline $\begin{array}{l}\text { Bahçede ve sınıflarda biriken çöplerin günlük olarak toplanıp, okuldan uzaklaştırılma } \\
\text { durumu }\end{array}$ & 10 & 100,0 \\
\hline
\end{tabular}

Görüldüğü üzere, ilköğretim okullarının tamamında sınıflarda çöp kutusu bulunduğu, çöp kutularının içine poşet geçirilmiş olduğu ve çöplerin günlük olarak okuldan uzaklaştırıldığı görülmektedir. Standartlara göre, sınıflardaki çöp kutuları kapaklı ve içine poşet geçirilmiş olmalı, okul çöpleri koku yapmayacak, böcek ve kemiriciler için besin ve barınak teşkil etmeyecek, çevre ve görüntü kirliliği yaratmayacak şekilde toplanmalı ve ortadan kaldırılmalıdır (Tunca, 1971). Dolayısıyla okulların standartlara uygun olduğu söylenebilir.

Tablo 7. Yöneticilerin, “Sinıflar ve Koridorlar Hangi Sıklıkla Temizlenmektedir” Sorusuna Verdikleri Yanıtların Dă̆lımı

Sinıflar ve koridorlar her gün kimyasal temizleyicilerle paspas yapılmakta.

Haftada 2-3 kez sinıflar paspas yapılır, ayda bir kimyasal temizleyicilerle

temizlenir

Sınıf ve koridorlar her gün sadece süpürülmekte.

Sinıflar ve koridorlar haftada üç kez süpürülmekte.

Toplam

\begin{tabular}{|c|c|} 
& $(\%)$ \\
\hline 5 & 36.0 \\
5 & 36.0 \\
3 & 21.0 \\
1 & 7.0 \\
14 & 100 \\
\hline
\end{tabular}

Tablo 7'de görüldüğü üzere, okulların büyük çoğunluğu paspas yapılarak, geri kalanı da yalnızca süpürülerek temizlenmektedir. Ancak okulların yalnızca yarısının her gün kimyasal temizleyicilerle paspaslanmakta olduğu görülmektedir.

Yöneticiler okulların sadece on okuldan birinde öğle yemeği verdiğini söylerken; okulların \% 90'ının öğle yemeği vermediğini belirtmektedir.

Tablo 8. Yöneticilerin, “Okul Kantininde Simit, Poğaça, Börek Gibi Açık Yiyecekler Satılıyor mu?” Sorusuna Verdikleri Yanıtların Dă̆ılımı

\begin{tabular}{|l|c|c|}
\hline & Okul Sayis & $(\%)$ \\
Evet & 7 & 70,0 \\
\hline Hayır & 3 & 30,0 \\
Toplam & 10 & 100,0 \\
\hline
\end{tabular}

Tablo 8'de görüldüğü gibi on okuldan yedisinde simit, poğaça ve börek gibi açık yiyecekler satılıyor ve üçünde satılmıormuş.

Tablo 9. Yöneticilerin, “Kantinden Öğrenciler Aşă̆ıdaki Yiyeceklerden Hangilerini Satın Alabilirler” Sorusuna Verdikleri Yanıtların Dă̆ılımı

\begin{tabular}{|c|c|c|}
\hline & Okul Sayıs1 & $(\%)$ \\
\hline Çikolata & 9 & 16,7 \\
\hline Bisküviler, krakerler, kekler ve benzeri besinler & 8 & 14,8 \\
\hline Meyve sular1 & 8 & 14,8 \\
\hline Süt & 8 & 14,8 \\
\hline Şekerleme & 6 & 11,1 \\
\hline Gazozlar & 5 & 9,3 \\
\hline Cips tarzı yiyecekler & 4 & 7,4 \\
\hline Meyve & 3 & 5,6 \\
\hline Diğer & 3 & 5,6 \\
\hline Çorba & 0 & 0 \\
\hline Toplam & 54 & 100,0 \\
\hline
\end{tabular}


Tablo 9'da görüldüğü üzere, on okulun altısında çikolata, hamur işleri, şekerleme, gazoz ve cips tarzı yiyecekler; bir okulda meyve ve süt satılmakta; okulların hiçbirinde çorba satılmamaktadır. Okul kantinlerinde büyük oranda besin değeri düşük ve sağlığa zararlı ürünler satıldığı söylenebilir.

\section{TARTIŞMA}

Araştırma kapsamına alınan okulların 2/3'ünden fazlasının öğretim şekli ikili öğretimdir. Türkiye genelinde ilköğretim okullarının \% 77,9 öğretim şekli tekli öğretimdir ve \% 22,1 ilköğretim okulunun öğretim şekli de ikili öğretimdir (MEB, 2010-2011). Tekli öğretim yapan ilköğretim okullarında, sabah saatlerinde eğitim-öğretim ikili öğretim yapan ilköğretim okullarına göre daha geç bir saatte başlaması çocukların kahvaltı yaparak okula gelmelerini, uykularını almalarını daha olanaklı kıldığı için tekli öğretimin, öğrencilerin gelişimi ve başarısı üzerinde olumlu etkilere sahip olduğu düşünülmektedir.

Okulların tamamının 3 ve daha fazla katlı olduğu belirlenmiştir. Oysa Okul Çevre Sağlığı Standartlarına göre okul binalarının tek katlı olması en uygunudur (Aydoğdu, 2007). Çünkü tek katlı okullarda yüksek pencereler, merdiven gibi yapılar olmayacağından düşme gibi kazalara daha az rastlanabilir. Deprem, yangın gibi acil ve binanın derhal boşaltılması gereken durumlarda kolaylık sağlayabilir. Ancak araştırmanın yapıldığ 1 bölgede tek katlı okul binasının olmadı̆̆ 1 saptanmıştır. Aslında bu durumun ülkenin tamamında yaygın bir durum olduğu anlaşılmaktadır. Örneğin, Aydoğdu (2007) tarafından Sivas'ta yapılan araştırmada, okul binalarının yalnızca \% 5,6'sının tek katlı olduğu; Ankara'da yapılan bir araştırmada da okul binalarının tümünün bir-dört arasında kata sahip olduğu belirlenmiştir (Polat, 1998).

Okulların \% 90'nında 2. ve daha yukarı katlarında pencerelerde korkuluk olmadığı belirlenmiştir. Okul Çevre Sağlığı Standartlarına göre okul birden fazla katlı yapılmış ise üst katlardaki pencerelerden öğrencilerin sarkmasını önleyecek korkuluk (demir parmaklık) gibi tedbirler alınmalıdır (Pekcan, 2005). Bu durumun ülkenin genelinde yaygın bir durum olduğu anlaşılmaktadır. Örneğin, Aydoğdu tarafından 2007 y1lında yapılan çalışmada da okulların üst kat pencerelerinin hiçbirisinde korkuluk (demir parmaklık) bulunmamaktadır. Demirel (2003) tarafinda Isparta'da yapılan araştırmada ise üst kat pencerelerinin \%93,5'inde korkuluk olmadığı belirlenmiştir. Anılan araştırmaların sonuçları Manavgat'ta yapılan bu araştırma sonuçlarına benzemektedir.

Veriler okulların çoğunun kalabalık olduğunu ortaya koymaktadır. Okullarda aşırı kalabalıklaşma çeşitli sorunlara yol açmaktadır. Araştırma bulguları, aşırı kalabalık okul ve sınıflardaki öğrencilerin kalabalık olmayan okul ve sınıflardaki öğrenciler kadar başarı testlerinde yüksek puan alamadıklarını göstermektedir (Earthman, 2002). Manavgat ilçesinde derslik başına düşen ortalama öğrenci sayısı 41'dir. Bu durum olumsuz sayılabilir. Çünkü, eğitime destek programı adı altında gerçekleştirilen tip proje okulların planlanmasında ve uluslar arası standartlarda, derslikler 30 öğrenciye göre düzenlenmektedir. Bu nedenle hem öğrencilerin daha başarılı olmalarını hem de öğretmenlerin kaliteli bir eğitim vermelerini sağlamak için, eğitim ortamı olarak kabul edilen sınıflarda öğrenci sayısının üst sınırının 30 olması gerekli görülmektedir (Griffth 1998). Finn ve Achilles'in (1999) 4 yılda 12.000 öğrenci üzerinde yaptıkları araştırmada, küçük sınıfların (13-17 öğrenci) normal sınıflara göre (22-26 öğrenci) çok daha yüksek oranda akademik başarı gösterdiklerini kanıtlamışlardır. Corcoran ve arkadaşları tarafından 1988 yılında yapılan çalıșmada, aşırı kalabalıklaşmanın öğretmenler ve öğrencilerde yükssek oranda devamsızlıkla sonuçlandığı belirtilmiştir. Aydoğdu'nun (2007) Sivas'ta yaptığı araştırmada, okulların \% 38,5'inde sınıf başına düsen öğrenci sayısı 41 ve üzerinde bulunmuştur. Polat'ın (1998) Ankara'da yaptığı araştırmada bu oran \% 46'dır. Sınıf başına düşmesi gereken en fazla öğrenci sayısı 30 olarak belirtilse de, bu sayının sınıflar için çok fazla olduğu düşünülmektedir. Çünkü sınıflara düşen örgenci sayısı arttıkça bulaşıcı hastalıkların yayılma riski artacaktır. Sınıfların yeterli alana sahip olmaması, öğrenci başına düsen hava hacmini azaltarak, hava kalitesini düşürüp, uyku hali, konsantrasyon güçlüğü gibi durumlara yol açarak etkili öğrenmeyi azaltabilir. Öğrenci ve çalışanlarda kapalı ortam hava kirliliğine bağlı ortaya çıkan sağlık sorunları görülebilir. Uzun dönemli çalışmalarda, kalabalık okulların öğrenci başarısını olumsuz etkilediği kadar 
öğretmenlerin çalışmasını da negatif yönde etkilediği bulunmuştur. Kalabalık sınıflarda kişisel öğrenci ve öğretmen iletişiminin de imkansız olduğu belirtilmiştir (Earthman, 2004).

Rivera-Batiz and Marti (1995)'ni yaptığı araştırmada, öğretmenlerin \% 75'inden fazlası aşırı kalabalık sınıfların hem sınıf etkinliklerini hem de öğretim tekniklerini olumsuz şekilde etkilediğini ifade etmiştir. Öğrencilerin \% 40'a yakın bir oranı da yeni bir şey öğrenirken sınıflarında konsantre olmada sorun yaşadıklarını belirtmiştir. Finn and Achilles (1999) tarafında yapılan araştırmada, küçük sınıflardaki (13-17) öğrenciler, hem öğretmen gözetiminde olan hem de öğretmen gözetiminde olmayan normal sınıflardaki (22-26) öğrencilere kıyasla daha üstün akademik performans sergilediklerini tespit etmişlerdir (Aktara: Ehrenberg, Brewer, Gamoran, Willms, 2001). Amerika Bileşik Devletleri Eğitim Bakanlığı birçok temel analizin bir incelemesini gerçekleştirmiş ve araştırma sonuçlarının ilkokul sınıflarında sınıf mevcutlarını azaltmanın daha yüksek öğrenci başarısına yol açtı̆̆ 1 ve sınıf mevcutları 20 öğrencinin altına düşürüldüğü takdirde öğrenci başarısındaki ilgili artışın ortalama bir öğrenciyi \% 50'den \% 60'ın üzerinde bir orana taşıdığı sonucuna varmıştır (United States Department of Education, 2002).

On ilköğretim okulundan yedisinde revir, sekizinde ilk yardım dolabı, 9'unda hemşire bulunmamaktadır. Oysa okullarda idari ya da spor yapılan yerlere yakın bir bölümde revir; ilk yardım için $15 \mathrm{~m}^{2}$ lik bir ilk yardım odası; ve revirde bir ilk yardım dolabı, gerekli araç-gereç (aşılar, aşılar için buzdolabı, tansiyon aleti, derece, enjektör, pamuk, spanç, batikon vs.) ve bir muayene masası bulunmalıdır (MEB, 2003; Topçu, 1978). Bu 7 okulun standartlara uygun olmadığı belirlenmiştir. Aydoğdu'nun (2007) yaptığı benzer araştırmada da okulların \% 93,1'inde revir olmadığ1, Polat'ın 1998 yılında yaptığ 1 araştırmada ise revir olmama durumu bakımından Sivas İli'ndeki duruma yakın bir sonuç $(\% 93,7)$ ortaya çıkmış. Bu araştırma sonuçlarına göre, Manavgat’taki ilköğretim okullarının durumu Ankara ve Sivas'ta ki ilköğretim okullarından daha iyi olduğu söylenebilir.

On ilköğretim okulunun sekizinde okullarda ilk yardım dolabı bulunmaktadır. Milli Eğitim Bakanlığının 2003 yılında yayınladığ "İlköğretim Kurumları Yönetmeliği'nin 139. maddesine göre, "okulda, ilk yardım dolabı ile ilk yardım çantası ve bunlara ait araç ve malzeme bulundurulur, dolapta doktor reçetesi ile alınmayan ve doktor tavsiyesine göre kullanılması gereken ilâçlar bulundurulamaz ve öğrencilere kullandırılmaz" hükümleri yer almaktadır (MEB, 2003). Okullardan 2'sinin bu hükmü yerine getirmediği belirlenmiştir.

Araştırma kapsamındaki on ilköğretim okulunun 9'unda hemşire bulunmadığ 1 belirlenmiştir. Sadece bir okulda revirde görev yapan hemşire bulunmaktadır. Oysa revirde en az bir hemşirenin görev yapması gerekmektedir. 1961 yılında İlköğretim Yasası ile okullara doktor, hemşire ve sağlık memurunun tayin edilmesi kabul edilmiştir. Ancak bu gün hala hekimi, hemşiresi, sağlık memuru olan okul yok denecek kadar azdır. Okulların \% 90'nın yasa ve standartlara uygun olmadığı belirlenmiştir. Polat'ın 1998'de Ankara'da yaptığı araştırmada revirlerin \% 4,8'inde sağlık personeli olduğu, Aydoğdu (2007) tarafından yapılan araştırmada, okulların \% 6,9'unda revir bulunduğu, bunların da hiçbirisinde hemşire bulunmadığ 1 belirlenmiştir. Okulda görevli hemşire, öğrencilerin normal gelişimini kolaylaştıran aktivitelerde bulunur, sağlık ve güvenliği geliştirir, gerçek ve potansiyel sağllk problemlerine yönelik girişimlerde bulunur, vaka yönetimi çalışmaları yapar, öğrencinin ailesi ile uyumunu, öz sorumluluğunu, haklarını savunma becerisini ve öğrenme kapasitesini artırmaya çalışır (Ergün, 2003). İlköğretim dönemindeki çocukların sürekli büyüyüp geliştikleri, hareketli, heyecanlı ve yerinde duramayan enerjik bir dönemde oldukları unutulmamalıdır. Okullarda revir ve revirde görevli okul hemşiresinin olması ile öğrencilerin ve okul personelinin sağlı̆̆ının korunması ve geliştirilmesinde, yine bu döneme özgü sağlık sorunlarının erken tanı ve tedavisinde, oluşabilecek kaza ve yaralanmalarda ilk yardım yapılmasında, büyüme ve gelişmenin izlenmesi ve bu alandaki sorunların belirlenip erken tedavisinde önemli katkılar sağlanacağı kuskusuzdur. Bu nedenle okulların her birinde revir bulunmalı ve her revirde bir hemşire görev yapmalıdır. Ancak, araştırma sonuçları, Türkiye'nin başka illerinde de okulların revire sahip olmadığını ortaya koymaktadır, hemşire istihdam edilmemektedir. Ama okulların büyük çoğunluğunda ilk yardım dolabı bulunmaktadır. 
On okul binasının yedisinde duvarlarının nem, ses ve 1sıya karşı yalıtımın sağlanmadığı; bu okulların OÇSS'ye (Okul Çevre Sağlı̆̆ Standartlarına) uygun olmadığı saptanmıştır. Aydoğdu (2007) tarafından yapılan bir araştırmada, okul binalarının \% 87,5'inin duvar, yer ve tavanlarının nem, ses ve 1sıya karsı yalıtımının sağlanmadığı belirlenmiştir. OÇSS'ye göre okul binalarının duvar, yer ve tavanlarının nem, ses ve 1sıya karsı yalıtımı sağlanmış olmalıdır (İbili ve Yıldız, 1999). Yeterli yalıtımı sağlanmamış okullarda nemli ortamlar oluşarak astım gibi hastalıkların ataklarını tetikleyebilir, artan gürültüye bağlı olarak derse olan dikkat azalıp eğitimin kalitesini ve başarıyı düşürebilir, işitme sorunları ortaya çıkabilir. Isı kayıpları ise soğuk havalarda üşümeye ve grip, soğuk algınlığ gibi hastalıklara yol açabilir. Bu nedenle okul binalarının yeterli yalıtımı sağlanmalıdır (WHO, 2009). Araştırma kapsamındaki on ilköğretim okulunun 8'inde suların hiç kesilmediği ve okulların tamamının su kaynağının şebeke suyu olduğu ve sadece bir okulda şebeke suyu, su deposu ve su tankeri bulunduğu belirlenmiştir. Okulların tamamının çeşmelerinden akan suyun içmeye uygun olduğu belirlenmiştir. Fekal-oral (dışkı-ağız) yolla bulaşan pek çok enfeksiyon hastalığının kirli içme suları ile yayıldığı (WHO, 1998) dikkate alındığında bu sonuç dikkate değerdir. Aydoğdu tarafından 2007 yılında yapılan araştırmada, 72 okulun yalnızca birinde nadiren su kesinti olduğu ve okulların hepsinin şebeke suyu kullandığı saptanmıştır. Demirel'in (2003) Isparta'da yaptığ1 araştırmada okulların \% 98,4'ünde yeterli ve sağlıklı içme-kullanma suyu olduğu, suların \% 84,1'inin sürekli aktığ 1 \% 15,9'unda ise nadiren kesinti olduğu belirlenmiştir. Bu sonuçlar, Manavgat İlçesi ilköğretim okullarının su bakımından Isparta ve Sivas iline göre daha iyi olduğunu göstermektedir.

On okul bahçesinden yedisinde öğrenci başına $1 \mathrm{~m}^{2}$ ile $3 \mathrm{~m}^{2}$ arasında bir alan düşmektedir. Bir başka deyişle on okuldan yedisinin öğrenci başına düşen bahçe alanı yetersizdir. Oysa okul bahçelerinin en az $400 \mathrm{~m}^{2}$ ve öğrenci basına $5 \mathrm{~m}^{2}$ alan düşecek şekilde olması gerekir (Çağlayaner ve Gönenli, 1998; Karasolak, 2009). Buna göre incelenen on okuldan yalnızca üçünde öğrenci başına düşen bahçe alanının yeterli olduğu belirlenmiştir. Okulların 7'sinde öğrenci başına düşen okul bahçe alanın yetersiz olduğu görülmektedir. Aslında bu durumun ülkenin tamamında yaygın bir sorun olduğu anlaşılmaktadır. Örneğin, Polat'ın 1998 yılında Ankara'da yaptığı araştırmaya göre okulların \% 84,1'nin bahçesinin bulunduğu, \% 22,2'sinin bahçelerinin uygun olmadığı, Demirel'in 2003 yılında Isparta'da yaptığ 1 araştırmada ise okul bahçelerinin \% 64,9'unda öğrenci basına düşen alanın yetersiz olduğu belirlenmiştir. Aydoğdu'nun (2007) Sivas'ta yaptığı araştırmada ise okul bahçelerinin yaklaşık üçte birinin standartlara uymadığı belirlenmiştir.

Okulların tamamında okul bahçe zemini çocukların oyun oynamasına uygun olmayan beton, asfalt ve parke gibi materyallerle kaplıdır. Bu durum, on ilköğretim okulunun tamamında okul bahçe zeminlerinin çocukların oyun oynamasına uygun olmadığını ortaya koymaktadır. Çünkü beton, asfalt ya da diğer sert yüzeyler oyun alanı eşyalarının altında direkt olarak asla olmamalıdır. Oyun alanları çimen ya da toprak koruyucu kaplama olarak düşünülmemektedir. İyi yüzey malzemeleri kum, çakı1 (düz yuvarlak, bezelye büyüklügünde taşlar), talaş (ağaç yongası) ve sentetik yüzeydir ((U.S. Consumer Product Safety Commission, 2008). Oysa, ilköğretim okul yöneticilerinin tamamı okul bahçelerinin çocukların oyun oynamasına uygun olduğunu belirtmektedir. $\mathrm{Bu}$ sonuç okul yöneticilerinin okul bahçe oyun zemin alanlarının nasıl olması gerektiği konusunda öğrenme gereksinmeleri olduğunu göstermektedir.

Bilişsel kuramcı Piaget (1951) yaptığı araştırmada, oyunu çocukların düşünüş ve bilişini güçlendiren en uyumlu davranış olarak görmüştür. Farklı oyun türleriyle meşgul olarak, çocuklar gözel koordinasyonu ve duyuşsal-motor (sensorimotor) beceriler gibi becerilerin pratiğini yapıp bunları sağlamlaştırırlar. Saracho ve Spodek (1995) tarafindan yapılan araştırmada oyunun her bir çeşidinin çocukluğun farklı aşamalarında bilişsel gelişim için şart olduğu belirtilmiştir. Ancak çocukların en başta gelen oyun alanlarından biri olan okul bahçelerinin durumunun Türkiye'de genelde standartlara uygun olmadığ

Bahçe zemininin uygun olmaması çocuklar oyun oynarken ya da spor yaparken kazalara ve yaralanmalara neden olabileceği gibi, oyun alanını kısıtlamakta, kötü hava şartlarında ise bahçede su birikintilerine ve göllenmelere neden olabilmektedir. Bahçesi bulunmayan ve standartlara uymayan 
okullarda, çocukların en önemli gereksinimlerinden biri olan oyun için uygun ortamlar sağlanamaz. Oysa çocuklar oyun oynayarak gelişmekte, öğrenmekte ve olgunlaşmaktadır. Okullar çocukların oyun oynamalarına firsat verirken, aynı zamanda toplumsal bir ortam da hazırlamaktadırlar. Böylece çocuklar oyun içinde girdikleri toplumsal ilişkilerle kurallara uymayı, paylaşmayı, sorumluluk almayı ve işbirliği yapmayı öğrenmektedirler (Morrison, 2002).

On ilköğretim okulunun tamamında okul bahçelerinde çöp kutuları mevcuttur. Ancak okulların 2'sinde okul çöplerinin biriktirildiği çöplüğün, oyun alanından uzak olmadığı belirlenmiştir. Okulların 2'sinin standartlara uygun olmadığı görülmektedir. Bu durumun ülkemizin değişik yerlerinde de yaygın biçimde gözlendiği anlaşılmaktadır. Örneğin, Aydoğdu'nun (2007) Sivas’ta yaptığ1 araştırmada araştırma kapsamındaki okulların yaklaşık yarısının bahçesinde çöp kutusu bulunmaktadır ve bu çöp kutularının üçte biri standartlara uygun değildir. Demirel'in 2003 yılında yaptığı araştırmada da, okul bahçelerinin tümünde çöp kutusu olduğu, ancak çöp kutularının yarısına yakınının standartlara uymadı $\breve{1}$ belirlenmiştir.

Okulun çöpleri koku yapmayacak, böcek ve kemiriciler için besin ve barınak teşkil etmeyecek, çevre ve görüntü kirliliği yaratmayacak şeklinde toplanmalı ve ortadan kaldırılmalıdır. Çöp toplanılan yerler belirli aralıklarla uygun dezenfektanlarla temizlenmelidir. Kağıt ve cam gibi geri dönüşümlü çöpler ayrı yerlerde toplanarak gerekli yerlere gönderilmelidir (Tunca, 1971). Okul bahçelerinde çöp kutularının olmaması çevre kirliliğine neden olurken, çöp kutularının standartlara uygun olmaması çeşitli haşerelerin üremesine ve bulaşıcı hastalıkların daha kolay yayılmasına neden olacaktır. $\mathrm{Bu}$ nedenle okul bahçelerinde çöp kutuları bulunmalı ve bu çöp kutuları standartlara uygun özellikler taşımalıdır. OÇSS'ye (Okul Çevre Sağlı̆̆ Standartları) göre okulda biriken çöplerin günlük olarak toplanıp, okuldan uzaklaştırılması gerekir. Bu işlemin daha az sıklıkta yapılması yeterli değildir (WHO, 2009). Bu durum okulda olumsuz görüntülere yol açtığı gibi, öğrenci ve okul personeli için enfeksiyon açısından risk oluşturabilir.

Okul yöneticileri okulların tamamında okul bahçesinin çevre duvarı olduğunu belirtmektedir. OÇSS'e göre okul bahçesi çevrili olmalıdır (Aydoğdu, 2007). Okulların hepsinin bahçe duvarları açısından standartlara uygun olduğu görülmektedir. Ancak, Türkiye'de yapılan diğer başka araştırmalarda okul bahçe duvarlarının yetersizliğini ortaya koymaktadır. Örneğin, Aydoğdu'nun (2007) Sivas'da yaptığ 1 araştırmada okulların yaklaşık üçte birinin bahçe alanının standartlara uymadığı, bahçelerin yalnızca \% 9,7'sinin etrafının çevrili, \% 86,1'nin ise etrafının çevrili ancak yetersiz olduğu belirlenmiştir, Polat'ın (1998) Ankara'da yaptığı araştırmaya göre okulların \% 84,1'nin bahçesinin bulunduğu, \% 22,2'sinin bahçelerinin uygun olmadığı ve \% 13'ünün etrafinın çevrili olmadığı belirlenmiştir.

İlköğretim okullarının tamamına yakınında kız ve erkek öğrenciler için tuvalet kabin sayıları ve lavabo sayıları yeterli değildir. Standartlara göre her katta kız ve erkek öğrenci tuvaleti bulunmalıdır. U.K. National Bog (Derby City Bog) Standartlarına göre 5 yaşın üzerindeki her 15 kız ve erkek öğrenci için bir tuvalet kabini ve bir lavabo bulunması uygun bulunmuştur. $\mathrm{Bu}$ araştırmada U.K. National Bog standartlara yaklaşan yalnızca iki okul bulunmaktadır. İlköğretim okullarının tamamına yakınında kız ve erkek öğrenci tuvaletlerindeki kabin sayısının ve lavabo sayısının yeterli olmadığı görülmüştür. Türkiye'de yapılan diğer başka araştırmalarda kabin sayısı yetersizliğini ortaya koymaktadır. Aydoğdu (2007) tarafindan yapılan araştırmada, okulların \% 66,7'sinde kız öğrenci tuvaletlerindeki kabin sayısı yetersiz sayıda belirlenmiştir. Antalya'da yapılan araştırmada okulların \% 64,2'sinde ((Baharlı, Dönmez,1998), Ankara'da yapılan benzer bir araştırmada ise, \% 29,6'sında öğrenci tuvaletlerinin standartlara uygun olmadığı ve yetersiz olduğu belirtilmiştir (Polat 1998).

İlköğretim okullarının tamamının tuvaletlerinde sürekli olarak sabun bulundurulmakta, ancak sürekli olarak tuvalet kağıdı bulundurulmamaktadır. Bakımlı, temiz görünümlü, kötü kokmayan, sabun, lavabo, çalışır durumda sifon ve her kabinde bir çöp kutusu ile bir askı bulunan tuvaletler standartlara uygun olarak değerlendirilir. U.K. National Bog (Derby City Bog) Standartlarına göre her lavaboda bir sabun bulunması ve tuvaletlerin kötü kokmaması kriteri getirilmiştir . U.K. National Bog (Derby City Bog) Standartları kriterlerine tuvaletlerin sabun bulundurma bakımından uygun olduğu 
bulunmuştur. U.K. National Bog (Derby City Bog) Standartlarına göre tüm öğrenciler için tuvalet kağıdı bulunmalıdır ve tuvalet kağıtları bir günde en az iki kez stoklanmalıdır. Dolayısıyla U.K. National Bog (Derby City Bog) Standartlarına göre tuvaletlerin \% 60'nın tuvalet kağıdı bulundurma bakımından kriterlere uygun olmadı ̆̆ı söylenebilir.

İlköğretim dönemi temel sağlık ve temizlik alışkanlıklarının kazanılmasında çok önemli bir dönemdir. Bazı araştırmalarda tuvaletini yaptıktan sonra tuvalet kağıdı kullanma ve sabun ile el yıkama alışkanlığının çocukları çeşitli paraziter hastalıklardan koruduğu belirtilmiştir (Temel ve diğerleri, 2006). Ancak, Türkiye'nin çeşitli illerinde ilköğretim okulu öğrencileri üzerinde yapılan araştırmalarda, \% 25,8 ile \% 62,6 oranları arasında parazit görüldüğü belirlenmiștir (Değerli ve diğerleri, 2006; Kaplan ve diğerleri, 2002; Şaşmaz ve diğerleri, 2001). Paraziter hastalıklar ve tuvalet sonrası sabun ile el yıkama alışkanlığı arasında ilişki olduğu düşünülebilir.

Okulların yarısının her teneffüs sonrası tuvaletlerinin temizlendiği belirlenmiştir, diğer yarısının temizlenme sıklığının standartlara uygun olmadığı görülmemektedir. Öğrenci sayısı çok olan okullar için günde iki kez temizlik sayısı yetersiz olup bu okulların standartlara uygun olmadığı söylenebilir. U.K. National Bog (Derby City Bog) Standartlarına göre ilköğretim okullarında tuvaletler, öğrenci sayısı tuvalet başına 25 ve daha az öğrenci için günde en az iki kez temizlenmelidir. Okulların \% 50'sinin temizlenme sıklığının U.K. National Bog (Derby City Bog) Standartları Kriterlerine uygun olmadığı görülmektedir.

Okulların büyük çoğunluğu paspas yapılarak, geri kalanı da yalnızca süpürülerek temizlenmektedir. Ancak okulların yalnızca yarısının her gün kimyasal temizleyicilerle temizlendiği görülmektedir. Kimyasal temizleyicilerin öğrencilerin okulda olmadığı zamanlarda kullanılması gerekmektedir. Aksi takdirde istenmedik durumlara sebep olabilir. Kapalı mekanlardaki havanın kirli olması astım, alerji ve bulaşıcı ve solunumsal hastalıkların oranlarını artırabilir ve öğrencilerin, konsantre olma, hesap yapabilme ve ezber gibi zihinsel aktivitelerindeki performansını da olumsuz yönde etkileyebilir. Birleşmiş Milletler tarafindan yapılan araştırmada, okulların yarısından fazlası, kapalı alanlarındaki havanın kalitesini düşüren en az bir çevresel problem bildirmiştir. Bu problemler; küflenme ve zehirli mantar oluşması; böcek ilaçları; temizlik ürünlerinden ve fotokopi makinelerinden çıkan uçucu organik kimyasallar; sınıflardaki eşyalar; radon gazı ve dış havadan okul binasına giren kirletici maddeler; yalıtımdan kaynaklanan havayla bulaşan yanmaz taş ve boyalardan ya da diğer bina malzemelerinden çıkan kurşun gibi çevresel etmenlerdir. Yanlış 1sıtma, havalandırma ve iklimlendirme ve temizleme sistemleri havanın kalitesine zarar verebilir (WHO, 2009).

Yöneticiler on okuldan birinde öğle yemeği verdiğini belirtmektedir. On okuldan yedisinde simit, poğaça ve börek gibi açık yiyecekler satıldığ 1 ve üçünde de satılmadığ 1 belirlenmiştir. Çalışmalarda, açıkta satılan ürünlerin sağlığa zararlı olduğu belirtilmektedir. Örneğin, 2002 yılında UNESCO, her yıl yaklaşık 5500 çocuğun bakteri içeren gıda tükettikleri için yaşamını yitirdiğini ortaya çıkarmıştır. E. Coli bakterileri, çocuklarda çok tehlikeli olabilen ishal ve böbrek yetmezliğine sebep olan başlica etmendir. Bunun en büyüğü 1996 yılında meydana gelmiş, yaklaşık 6300 öğrencinin ve 92 personelin hastalanmasına sebep olmuş ve iki kişinin ölümüne yol açmıştır. Gelişmekte olan ülkelerde, su kaynaklarının güvenilir ve sıhhi temizliğin yeterli olmadığı kirli çevrelerde gıda zehirlenme riski daha fazladır (WHO, 2009). Okul kantinlerinde büyük oranda çikolata, hamur işleri, şekerleme, gazoz ve cips gibi besin değeri düşük ve sağlığa zararlı besinler satılmaktadır. 


\section{Kaynaklar}

American Academy of Pediatrics. 1993. Committee on School Health, School Health Policy and Practice, Fifth Edition.

Antalya İl Milli Eğitim Müdürlüğü. 2010. Ylllık İstatistikler, Antalya, Antalya İl Milli Eğitim Müdürlügü̈.

Aydoğdu, N. 2007. Sivas il Merkezindeki İlköğretim Okullarında Fiziksel Çevre Koşullarının Değerlendirilmesi. Yayımlanmamış yüksek lisan tezi, Cumhuriyet Üniversitesi Sağlık Bilimleri Enstitüsü, Sivas.

Babayiğit, M. A., Bakır, B., Tekbaş, Ö.F., Oğur, R., Kılıç, A. ve Hasde, M. 2010. Ankara Keçiören İlçe Milli Eğitim Müdürlüğü'ne Bağlı İlköğretim Okullarının Çevre Sağllğı Standardına Uygunluk Durumunun Değerlendirilmesi. Türkiye Halk Să̆lı̆̆ Dergisi. 8 (1), 19-29.

Baharlı N. ve Dönmez L. 1998. Antalya Kent Merkezindeki İlkokullarda Bazı Çevre Sağlığı Değerlerinin Durumu. Sağllk ve Toplum, 8(2):20-25.

Corcoran, T.B., Walker, L.J., and White, J.L. 1988. Working in urban schools. Washington, DC: Institute for Educational Leadership.

Çağlayaner, H., Gönenli, H. 1998. Etkin Eğitim Açısından Okul Sağlı̆̆ı. Aile Hekimliği Dergisi, 2(1), 31-39.

Degerli S., Çeliksöz A., Aslan A., Acıöz M., Özçelik S. 2006. İlköğretim Okulu Öğrencilerinde Altı Ay Arayla Yapılan Dışkı İncelemesi Sonuçlarını Karşılaştııılması. Türkiye Parazitoloji Dergisi, 30 (4), 305-307.

Demirel R. 2003. Isparta İl Merkezindeki İlköğretim Okullarında Okul Sağlığı Araştırması, Uzmanlık Tezi, Isparta.

Department opf Health and Human Services Centers For Disease Control and Prevantion. 2006. School Health Policies and Programs Study. www.cdc.gov/shpps

Earthman, Glen I. 2002. School Facility Conditions and Student Academic Achievement. Virginia Polytechnic Institute. UCLA's Institute for Democracy, Education, \& Access. Web: www.ucla-idea.org aresinden 10 Ocak 2009 tarihinde alınmıştır.

Ehrenberg, . G.E., Brewer, D.J., Gamoran, A.., Willms, J.D. 2001. Class Size and Student Achievement. Psychological Science in the Public Interest. 2, ( 1) , 1-30.

Ergün A. 2003 Hemşirelik Bakımı Sınıflama Modelleri Doğrultusunda Okul Sağlığı Hemşireliği Uygulamaları, İstanbul Üniversitesi Sağlık Bilimleri Enstitüsü Hemşirelik Anabilim Dalı, Doktora Tezi, İstanbul.

Finn, J.P. \& Achilles, C.M. 1999. Tennessee's class size study: Findings, implications and misconceptions. Educational Evaluation and Policy Analysis, 21, 97-110.

Griffth J. 1998. The Relation of School Structure and Socual Envireonmentto Parent Involvemement in Elementary School, The Elementary School Journal, Vol: 99, N: 1, p: 53-80.

Juszcak, L. 1999. Okul Temelli Sağllk Hizmetleri. Okul Sağlığı Kongresi Bildiri Kitabı, Sayfa:5-6. 13-17 Ekim 1999, İstanbul.

Jones, S.E., Axelrad , R., Wattigney, W.A. 2007. Healthy and Safe School Environment, Part II, Physical School Environment: Results From the School Health Policies and Programs Study 2006. The Journal of School Health. Ekim 2007. Vol. 77, Iss. 8, pg. 544.

Jones, S.E., Fisher, C. J.F., Grene, B.Z., Hertz , M.F., Pritzl ,J. 2007. .Healthy and Safe School Environment, Part I: Results From the School Health Policies and Programs Study 2006. The Journal of School Health. Kent: Oct 2007. Vol. 77, Iss. 8, pg. 522.

Karabayır, E. 2004. Okul Yöneticilerinin Okul sağlığını Algılamaları ve Hizmetiçi Eğitim İhtiyaçlarının Belirlenmesi. Yayımlanmamış yüksek lisans tezi, Eğitim Yönetimi ve Denetimi

Karasolak, K. 2009. Mimari Özellikleri Farklı İlköğretim Okullarındaki Öğrenci Ve Öğretmenlerin Okullarının Bina ve Bahçeleri Hakkındaki Görüşlerinin İncelenmesi. Yayımlanmamış yüksek lisans tezi, Çukurova Üniversitesi Sosyal Bilimler Enstitüsü, Adana.

Kaplan M., Polat, S.A., Erensoy, A. 2002. İlköğretim Okulu Öğrencilerinde Barsak Parazitlerinin Görülme Siklı̆ğ. 8.Ulusal Halk Sağlığı Kongre Kitabı I, s: 309. 
Ku Band, J., Steel, S.A. 1995. School Health, In Community Helath Nursing Theory and Practice. Ed: Smith CM Maurer FA, W.B Saunders Co Philadelphia, P. 429-449, 745-775.

Leger, 1.H. St. 1999. The Opportunities and Effectiveness Of The Health Promoting Primary School In Improving Child Health-A Review Of The Claims and Evidence. Health Education Research Vol.14 No.1 1999, 51-69.

Milli Eğitim Bakanlığı. 2003. İlköğretim Kurumları Yönetmeliği. Ankara: Milli Eğitim Basım Evi.

Milli Eğitim Bakanlığı. 2011. 2010-2011 Milli Eğitim İstatistikleri, Örgün Eğitim.

Morrison G.S. 2002. Günümüzde Erken Çocukluk Eğitimi, Milli Eğitim Dergisi, Sayı 151.

Pekcan, H. 2005.Okullarda Să̆lı̆̆ın Korunması ve Çevre Să̆lı̆̆ı. Bilimsel Eğitim Toplantısı ve uygulama Kitabı, Ankara, s. 19.

Piaget, J. 1951. Play, Dreams and Imitation in Childhood. London: Heinemann.

Polat, H. 1998. Ankara Merkez İlçelerindeki Okulların Çevre Să̆lı̆̆ı Yönünden İncelenmesi (Uzmanlık Tezi). Hacettepe Üniversitesi Sağlık Bilimleri Enstitüsü, Ankara. S. 28-60.

Rivera-Batiz, F.L., and Marti, L. 1995. A School System at Risk: A Study of the Consequences of Overcrowding in New York City Public Schools. New York: Institute for Urban and Minority Education, Teachers College, Columbia University.

Saracho, O.N., \& Spodek, B. 1995. Preparing teachers for early childhood programs of linguistic and cultural diversity. In E. E. García, B. McLaughlin, B. Spodek, \& O. N. Saracho, O. N. (Eds). Yearbook of Early Childhood Education: Meeting the Challenge and Cultural Diversity in Early Childhood Education, Vol. VI (pp. 154-169). New York: Teachers College Press.

Sarp, Nilgün. (1999). Okul Sağlı̆̆l. Okul Sağlığı. Milli Eğitim Bakanlığı Sağlık İşleri Daire Başkanlığı, Ankara, $1-5$.

Sur, H. ve Uz, M.H. 1994. Okullarda Çevre Sağlı̆̆ının Değerlendirilmesi:Bir Kontrol Listesi Önerisi.Web:http://66.102.9.104/search?q=cache:uP8e6DsnmaMJ:ww.sabem.saglik.gov.tr/Akademik_Meti nler/goto.aspx\%3Fid\%3D1594+okul+\%C3\%A7evre+sa $\%$ C4\%9Fl\%C4\%B1\%C4\%9F\%C4\%B1\&hl=tr\&ct $=$ clnk \&cd $=3 \& \mathrm{gl}=$ tr\&lr=lang_tr.

Spurrel, J. 2006. Comprehensive School Health, The Social Determinants of Health and the Health Status of Children. Faculty of Applied Health Sciences, Brock Üniversty, St, Catharines, Ontaria. Master of Science. 28-41.

Şaşmaz T., Demirhindi H., Akbaba M. 2001. Adana'da Bir İlköğretim Okulunda İntestinal Parazit Taşıyıcılığı ve Malnütrisyon Sıklığının Araştırılması. Să̆lık ve Toplum, 11 (3).

Taymaz, H. 2003. Okul Yönetimi. 7. Baskı. Ankara: Pegem yayıncılık. S. 4.

Temel, F., Akın, L., Vaizoğlu, S.A., Kara, Ö., Halas, A.M., Gurunaidu, S.S., Oğur, R., Tekbaş, Ö.F., Güler, Ç. 2006. Altındağ ilçesindeki bir ilköğretim okulunda suyun ve tuvalet, musluk ve kapı kollarının sürüntü örneklerinin değerlendirilmesi. Gülhane Tip Dergisi,48, 70-74.

Topçu, T. 1978. Etimesgut Sağlık Ocă̆ı Bölgesinde Bir Okul Să̆lı̆̆l Çalışması. Uzmanlık Tezi. Hacettepe Üniversitesi Tıp Fakültesi, Ankara.

Tunca, Y. 1971. Okul Sağlı̆̆1 ve Sağlık Eğitimi. İstanbul: Milli Eğitim Basımevi.

UK. 2010. Derby City Healty Schools Bog Standard Award School Toiletts Matter, http://www.localinnovation.idea.gov.uk/idk/aio/8496558,

U.K. National Bog Standard. 2009. Derby City Healthy Schools. Bo Standard Award School Toilets Matter. Web:http://localinnovation.idea.gov.uk/idk/aio/8496558 adresinden 10 Mayıs 2009 'da alınmıştır.

United States Department of Education. 2002. Reducing class size:What do we know? Washington, DC: The Department of Education. Web: http//ed.gov/pubs/ReducingClass/Class_size.html adresinden 10 Aralık 2010'da alınmıştır. 
U.S. Consumer Product Safety Commission. 2008. Public Playground Safety Handbook. Saving Lives and Keeping Families Safe. http://www.cpsc.gov/cpscpu

World Health Organization (WHO). 1998. Primary School Physical Environment and Health. Global School Health Initiative. Who information Series on School Health: Document Two. Who/ School/ 97.2, Who/EOS/97.15, WHO, Geneva.

World Health Organization (WHO. 2008). The Physical School Environment: An Essential Component of Health Promoting School. WHO Information Series on School Health Document 2. http://www.who.int/school_youth_health/media/en/physical_sch_environment.pdf

World Health Organization (WHO. 2009) The Physical School Environment An Essential Component of Health Promoting School. The World Health Organization's Information Series on School Health Document 2. http://www.who.int/school_youth_health/media/en/physical_sch_environment_v2.pdf. 